\title{
Non-Sense Mediated Decay Mutation
}

National Cancer Institute

\section{Source}

National Cancer Institute. Non-Sense Mediated Decay Mutation. NCI Thesaurus. Code C148643.

A mutation occurring in a sequence that regulates non-sense mediated mRNA decay. 